\title{
CHRISTIAN MISSION AMONG OTHER FAITHS
}

\author{
S. Devasahayam Ponraj*
}

\section{INTRODUCTION}

The primary purpose of this paper is to evaluate the Edinburgh 1910 Conference in terms of the conference's stand on "Christian mission among other faiths." From all accounts it was clear that the Conference stood for the soul purpose of reaching the people of nonChristian religions as expressed in the reports of the Conference.

The second purpose is to find what went wrong over the years subsequent to the Edinburgh 1910 and why the expected progress was not made in "world evangelization" in terms of reaching the people of other faiths. There are obvious reasons such as the two world wars, the fall of the colonial powers, and the resurgence of nationalism and of nonChristian religions. These were the external forces on which the Christian faith had very little power. But there were internal and more subtle reasons that worked within the Edinburgh 1910 movement and among its leaders, who wrote and expounded their views on reaching the people of other faiths.

The third purpose will be to interpret Edinburgh 1910 for present-day opportunities and challenges in terms of reaching people of other faiths. We need to study how we have to handle the opportunities and challenges that are ahead of us so that the dreams of Edinburgh 1910 can be realized in the years following 2010.

\section{EDINBURGH 1910}

The historical World Missionary Conference at Edinburgh in 1910, was outstanding for its spirit of confidence and determination to take the gospel to the whole world. "The Evangelization of the World in this Generation" was the trumpet call given by the great missionary statesman, the American Methodist, Dr. John Raleigh Mott (1865-1955), and this call was heard far and wide and the response was overwhelming. It was a call that gave inspiration to the younger generation of Americans for foreign missions. In later years hundreds responded to this call and went as missionaries to foreign mission fields.

The participants of the Conference, over 1200 representatives from all over the world, had dreams of great expectations in terms of world evangelization in their generation. met in a spirit of enthusiasm and optimism. ${ }^{1}$ The men and women of Edinburgh 1910 were

\footnotetext{
* S. Devasahayam Ponraj and his wife Sheila have been missionaries in North India for the past 36 years. He is an ordained minister of Church of North India and the Evangelical Church of India. He is an author and publisher of Mission Educational Books. At present Ponraj serves Bihar Out-Reach Network (BORN) as its General Secretary. Ponraj and Sheila have three grown up Children and five grand children.

${ }^{1}$ Roger E. Hedlund, Roots of the Great Debate in Mission,(Chennai: Evangelical Literature Service,1981), 29.
} 
not idle dreamers but knew what they were dreaming. They had seen the advancement of the Gospel in the previous century. Because of the success of the missionary efforts in the 1800 s, the century ending in 1914 was later given the title "The Great Century."1 Therefore they had every reason to justify the hope that very rapid expansion might not be beyond the powers of the western Churches. ${ }^{2}$ Bishop Stephen Neill observed, "All the dreams of Edinburgh 1910 have not been fulfilled. Yes, when we consider what has been achieved in spite of the disasters of two world wars, it is clear that the men and women of Edinburgh 1910 were not idle dreamers; they had both feet firmly planted on the ground." 3

\section{EDINBURGH 1910'S STAND ON CHRISTIAN MISSION AMONG OTHER FAITHS}

Careful planning and thorough research were done prior to the Conference. Part of the research was that the Executive Committee of the Conference appointed eight Commissions to look into various issues related to world evangelization. One of those commissions was "The Missionary Message in Relation to Non-Christian Religions."4 Each Commission was led by eminent missionaries from the field as well as from academic and church backgrounds. The primary message of the conference was understood as the evangelization of the non-Christian world. ${ }^{5}$ It is important to note that there were two commissions focused on reaching people of other faiths: Commission I "Carrying the Gospel to all the Non-Christian World," and Commission IV "The Missionary Message in Relation to Non-Christian Religions." Both Commissions had several common features relating to "the people of other faiths."

Commission I stressed the urgency and opportunity for evangelism. A survey of the nonChristian world was presented and statistics and other data provided firm answers and pressed for further evangelization efforts. ${ }^{6}$ On the other hand, the Report of Commission IV spoke of the necessity of a "sympathetic attitude toward India's most ancient religion" on the part of the missionaries. Dr. Roger Hedlund, quoting from the Conference Report, observes, "A point was made that they should try to understand Hinduism. Sympathetic understanding did not, however, displace the motive of evangelism. Edinburgh optimistically believed in the unanswerable appeal of the life of Christ to Hindus."7 The Report concluded, "It is the influence which this positive appeal has exerted during the past century, and the results that it is even now producing, which justify the hope that India will one day become a Christian country."

\footnotetext{
${ }^{1}$ Stephen Neill, The History of Christian Missions, (Middlesex: Penguin Books, 1984), 396.

${ }^{2}$ Neill, The History, 395.

${ }^{3}$ Neill, The History, 395.

${ }^{4}$ Report of Commission I-VIII- World Missionary Conference, Edinburgh, 1910.

http:www.archive.org/bookreader/ 12-5-2009.

${ }^{5}$ Ken Gnanakan, Kingdom Concerns, (Leicester: Inter-Varsity Press, 1993)m 16.

${ }^{6}$ Hedlund, The Roots of the Great Debate, 33.

${ }^{7}$ Hedlund, The Roots, 35.

${ }^{8}$ Hedlund, The Roots, 35.
} 
Edinburgh 1910 gave birth to the International Missionary Council (IMC), the first world-wide cooperative effort of its kind among Protestant mission bodies. It is important to note that one of the functions of the IMC was "to stimulate thinking and investigation of missionary questions" " which included how to present the gospel to other faiths. The continuation committee that was set up by the Conference under the leadership of John Mott organized a series of conferences in different parts of the world. In 1912 at the New Delhi Conference, it was recorded that "the conference realizes that there is a loud call for more direct preaching of the gospel all through the land and urges the importance of missions uniting for this purpose." 10 Such a high tempo was hindered as the First World War came and mission advancement was halted. Apart from the World Wars, what actually hindered the missionary advance in terms of reaching the nonChristian world was the internal confusion caused by the theological and missiological discussions and writings made by the leaders of the subsequent Conferences that were organized by the IMC.

\section{DIFFERENT APPROACHES TO WORLD EVANGELIZATION SINCE EDINBURGH 1910}

Following the Edinburgh 1910 Conference, the so-called guardians of the Christian faith failed the missionary movement by their irresponsible writings which took away the missionary zeal from the heart of the mission. The second of the great World Missionary Conferences, held at Jerusalem in 1928 brought "hesitant accents" and a doubtful message in contrast to the "confident tone of the Edinburgh pronouncements." 11 It was reported after the conference that "clearly a comprehensive change was taking place in theological climate, in attitudes to other religions, and in the understanding of the missionary task." 12 The Jerusalem conference became "syncretistic" when it entered into competition with non-Christian religions and philosophies. Trying to be relevant it followed the false premise of "attempting to demonstrate the 'uniqueness' and 'supreme value' of Christianity on the world's own terms. The mistake was to descend to the level of world religions."13

The following decades saw the fire that was kindled at the Edinburgh 1910 Conference towards reaching the people of the other faiths quenched by the successive writings and debates at the different world conferences. Ken Gnankan observed, "As one reads reports of those early conferences and of those held subsequently, it is hard to believe that the optimism and enthusiasm for evangelism with which IMC came into existence were so soon submerged by the concerns that have hampered and even opposed evangelistic efforts." In 1930s some theologians and missionaries advocated the "fulfillment theory" which strongly maintained that the Christian faith "comprehends" and "fulfills"

\footnotetext{
${ }^{9}$ Hedlund, The Roots, 16.

${ }^{10}$ Hedlund, The Roots, 16.

${ }^{11}$ Neill, The History, 455.

${ }^{12}$ Neill, The History, 455.

${ }^{13}$ Hedlund, The Roots, 52,53.

${ }^{14}$ Gnanakan, Kingdom Concerns, 17.
} 
all the partial truths found in the other religions, while at the same time purging them from their errors and supplementing them with truths and values that they do not in themselves possess. ${ }^{15}$ Dr. J. N. Farquhar, in his book The Crown of Hinduism (1930), applied this theory to Hinduism. After examining in details the beliefs and practices of the Hindus, he concludes, "Christ provides the fulfillment of the highest aspirations of Hinduism.... He is the Crown of the Faith of India." Even though this theory sounds reasonable, if we carefully analyze it, it does not stand true to biblical teaching as it cancels the uniqueness of Christ.

Then came advocates of the liberal theological position who maintained that "God's revelatory action in Christ is but one slice of the whole loaf of God's revelation in the history of religions, and this Christian portion cannot claim to be the whole of universal revelation and salvation...." ${ }^{16}$ One of the most publicized expressions of this view appeared in the book entitled Re-thinking Missions (1932), the Report of the (American) Laymen's Foreign Missions Enquiry. It was this Report which stirred up opposition and criticism. The Report stated,

...the task of the missionary today, it was maintained, is to see the best in other religions, to help the adherents of those religions to discover, or to rediscover, all that is best in their own traditions, to cooperate with the most active and vigorous elements in the other traditions in social reform and in the purification of religious expression. The aim should not be conversion - the drawing of members of one religious faith over into another - or an attempt to establish a Christian monopoly. Cooperation is to replace aggression. The ultimate aim, is so far as any can be described, is the emergence of the various religions out of their isolation into a world fellowship in which each will find its appropriate place. ${ }^{17}$

A report written in preparation for the International Missionary Conference held in Tambaram in India (1938) was the "Hocking Report," The Christian Message in a NonChristian World. Dr. Hendrik Kraemer of Holland, in response to the Hocking Report, argues that the Christian revelation is in its essence so entirely different from all other religions that there is, and can be, no point of contact between the one and the other. The Madras Conference to a large extent rectified Jerusalem's excesses with the writings of Kraemer. However, liberalism had taken over the place of evangelism and the mission of the church.

Stephen Neill points out, "A number of missionaries had come under the influence of the theology of liberalism. Yet it has proved impossible to go back to the earlier point of view; and the kind of propaganda on behalf of missions which was acceptable in the nineteenth century now makes little appeal in the more cultivated and thoughtful circles

\footnotetext{
${ }^{15}$ John T. Seamands, Tell it Well: Communicating the Gospel Across Cultures, (Chennai: Mission Educational Books, 2000), 43, 44.

${ }^{16}$ Seamands, Tell It, 48.

${ }^{17}$ Stephen Neill, A History of Christian Mission, 1984, 456.
} 
in the Church."18 As a result of this liberal view, "Tolerance was coming to be the most popular of all virtues, and conversion to be regarded as an outmoded phenomenon of religious experience." 19

Finally the International Missionary Council (IMC) merged with the World Council of Churches (WCC) at the New Delhi Conference in 1961. Great missionary statesmen like Max Warren, Leslie Newbigin and Stephen Neill opposed a merger. Warren opposed integration because he saw the necessity of voluntarism. Mission is carried out only by the committed who compromise the "spiritual vanguard" of the Church and who act through the vehicle of voluntary organizations of like-minded persons in order to achieve an agreed goal. ${ }^{20}$ Leslie Newbigin complained that "A movement which is not missionary has no right to use the word "ecumenical."" Stephen Neill expressed his reservations, "As things now are the IMC might simply be swallowed up as one among the many activities of the much larger organization."21 That's what had happened. Mission became one department of the ecumenical Church.

However, in the Indian context, the dream of Edinburgh 1910 was kept alive by the national Church as it gave birth to church-based voluntary and faith missions such as the Indian Missionary Society (1903), The National Missionary Society (1904), the Friends Missionary Prayer Band (1958), and the hundreds of such missionary agencies that have come into being during the past fifty years. The national Church and some of these agencies had to fight against the liberalism in the Church and they did win over liberalism by being faithful to the Word of God and to the mission of the local church.

\section{THEOLOGICAL UNDERSTANDING OF THE PRESENCE OF NON- CHRISTIAN RELIGIONS IN THE WORLD}

In the context of what went wrong after the Jerusalem conference in 1928, the publication of Rethinking Missions in 1932, and the liberalism that hindered world evangelization, we need to make our theological and missiological standing clear if we want to see the vision of Edinburgh 1910 being fulfilled in our generation in reaching the people of other faiths in India and other countries of the world.

In the Old Testament we see how God called the people of Israel as His covenant people for the nations (Genesis 12:1-3). They were called out of the nations but they were made to live among the nations who worshiped different gods and goddesses. During their exile, again they were called to live as His people among the people of other faiths. The book of Esther, Nehemiah and Daniel tells us how the people of God were living as His witnesses among people who worshiped other gods. Daniel and his friends, in spite of identifying with the culture of the Babylonians, stood for their faith and were willing to

\footnotetext{
${ }^{18}$ Neill, A History, 456,

${ }^{19}$ Neill, A History, 456.

${ }^{20}$ Hedlund, 84,85.

${ }^{21}$ Hedlund, The Roots, 85.
} 
face its consequences. Their faith in Yahweh and their loyalty to Him made the heathen kings to acknowledge that Yahweh, and not they, rules (Dan. 2:47; 4:1-37; 6:25-28).

Ida Glaser in her book, The Bible and Other Faiths, makes a detailed study on this subject and brings out this observation: "Some people say that, to live at peace with people of other faiths, we need to recognize their gods and even to pray with them. Deuteronomy tells Israel that she will live at peace only if she refuses to worship other gods." 22 To others who have the problem of worshipping and witnessing to Christ among non-Christian nations, Ida tells that, "Like Esther, Daniel answers a resounding 'Yes' to the question of whether God's people can live and worship without power, temple or land.",23

The Ten Commandments clearly teach that we should avoid all kinds of idol worship. "You shall have no other gods before me. You shall not make for yourself an idol in the form of anything in heaven above or on the earth beneath or in the waters below. You shall not bow down to them or worship them." And it is important to note that the punishments and the blessings are based on the "idol worship" as we read, "for I, the Lord your God, am a jealous God, punishing the children for the sin of the fathers to the third and fourth generation of those who hate me, but showing love to a thousand generations, of those who love me and keep my commandments" (Exodus 20:1-6). This calls for evangelists who are working with Hinduism to carefully avoid all kinds of compromise with idol worship. We should be clear in our teaching to the new believers who come from the Hindu faith.

\section{THE MEANING OF "WORLD EVANGELIZATION" TODAY}

In 1910 - when the Conference gave the call for "evangelization of the world in our generation," it was a call from the Western Church to the rest of the world. At that time the non-Western world was considered to be the non-Christian world. Stephen Neill observed, "Comparison between the state of mission in 1810, in 1860s, and in 1910 seemed to justify the hope that very rapid expansion might not be beyond the powers of the western Churches."24 But in today's context, "world evangelization" would mean "taking the gospel from everywhere to everywhere." 25 Today "world evangelization" means "reaching the whole world" in its truest sense. We repeatedly hear from the Western Church leaders that North America as well as Europe needs missionaries from Asia and Africa. For example, only 25 per cent of people in North America are "practicing Christians." The rest of the people, 75 per cent, need to be evangelized, by missionaries from the non-western countries like India and China. "World evangelization" would also mean evangelizing the diasporas who are scattered around the

\footnotetext{
${ }^{22}$ Ida Glaser, The Bible and Other Faiths, (Leicester: Inter-Varsity Press, 2005), 97.

${ }^{23}$ Glaser, The Bible, 111.

${ }^{24}$ Neill, A History, 395.

${ }^{25}$ This was the theme of the missionary conference (Atlanta, 1998) convened by the Presbyterian Frontier Fellowship of the Presbyterian Churches in USA.
} 
world. One of the concerns would be how to evangelize the South Asian diaspora in North America, Canada, Europe and the rest of the world.

\section{WITNESS TO THE UNIQUENESS OF JESUS IN A MULTI-RELIGIOUS WORLD}

Hocking's theory of reconception advocated that each religion should rethink or reconceive its own beliefs in the light of the essential beliefs of the other religions. This will produce a new world faith embodying the essential features of all, but different from any one of them. This will take time, Hocking admitted, so in the meantime we must be content with a peaceful coexistence of religions and with cooperation in worship and service. $^{26}$ If we carefully study this theory, as pointed out by Seamands, "it is a theological impossibility to reconceive the fundamental ideas of each religion in the light of the other religions and still maintain the essential essence of each."27

For example, how are the Muslim and Christian views of the person of Christ to be reconciled, when on one hand the Muslim claims that Jesus is not the Son of God, is not divine, did not die on the Cross, and did not arise from the dead; while on the other hand the Christian affirms all of these facts?

Another example would be, the Hindu would say to the Christian, "I happen to be a Hindu by birth and preference; you happen to be a Christian. Now if either one of us seeks to impose his religion upon the other, it only leads to misunderstanding and strife. So let us recognize one another's religion and live side by side in a state of 'peaceful religious coexistence.", 28 The question often asked by the non-Christians is that, "If the Christian can find some light, some values in all religions of the world what becomes of his 'Evangelism' to the non Christians?",29

Dr. Ebe Sunder Raj, the former General Secretary of the India Missions Association, gives the following answer to the questions, "If Christ's life and sayings be the ultimate Truth for a disciple of Christ, he can with all humility invite others, with neither apology nor arrogance, to come further up from where they stand, to see his Guru as the ultimate Truth. This calls for radical thinking, both from the Christian and those who oppose his mission." 30 Therefore, it is quite evident that all these forms of the liberal position are contrary to the truth expressed in the Christian Scriptures.

\section{WITNESS IN THE CONTEXT OF HINDUTVA AND HINDU MILITANCY}

\footnotetext{
${ }^{26}$ Seamands, Tell It, 50.

${ }^{27}$ Seamands, Tell It, 51.

${ }^{28}$ Seamands, Tell It, 30.

${ }^{29}$ Ebe Sunder Raj, National Debate on Conversion, (Mussoorie: Nivedit Good Book Distributors Pvt.Ltd.) 8.

${ }^{30}$ Raj, National Debate, 8.
} 
Christians are called for tolerance towards other religions. This is particularly felt in the context of militant Hinduism and militant Islam (Jihadis). While Hindus and Islamists freely practice militancy in India, Christians are expected to be "peace-loving" and tolerant citizens. If "freedom of religion" is equal for all religions, it should apply to Christianity too. Recently RSS Chief Mohan Bhagwat said that "The world faces serious problems today and only Hindutva can provide answers to these problems. Hindutva believes in the world as one family," Further he said, "Hindutva was the identity of the country." ${ }^{31}$ When someone talks about Hinduism, people do not attack or persecute the man. However, if a Christian says, "Gospel is the hope of India" or "Jesus is the answer to India's problems," we are told that "Christians are not patriotic" and we are persecuted. Why do we have this double standard in our secular country?

"It is an urgent challenge," writes Ken Gnanakan, "to adopt a positive attitude to other religions, seeing them all as valid. No longer can we hold an idea of uniqueness that will challenge other religious positions. In our world, being torn apart by various forces, Christians are called to seek a mutuality that will result in harmony."32 Gnanakan refers to Stephen Neill's caustic comment: "It has often surprised me that Christians alone should be required to be tolerant in a world in which no-one else is prepared to be tolerant." He cites all religions as propagandists, adding "The dedicated Marxist regards himself as a man with a mission. His sincerity demands that he should be a ferocious propagandist.... The Muslim is equally of the opinion that he has the whole truth..... To the Buddhist there is only one way.... All these are propagandist religions and make no secret of it." 33

\section{CHRISTIAN FAITH VERSUS NON-CHRISTIAN FAITHS: OUR CONVICTIONS}

We can summarize the discussion into three core beliefs or convictions.

1. Christianity vs. the world religions: We have to examine Christian faith in contrast to other non-Christian faiths in terms of what each religion has to offer. Take for example, in Hinduism there is general absence of any real sense of responsibility and therefore of sin. In most instances it is the knowledge of Christ which creates the sense of sin: "to the Christian the idea of sin, as the willful transgression of the law of God, lies at the very root of his whole conception of man's relation to God." 34

Again "the Hindu idea of God does not contain the thought of any holy and gracious Will from which forgiveness of sin, and deliverance from moral evil, may be looked for. The Gospel of Christ enlightens the conscience as to its great need, and is a message of

\footnotetext{
${ }^{31}$ Speech given by Mr. Mohan Bhagwat, at a rally at Pune, on the $15^{\text {th }}$ November, 2009 quoted by The Times of India, Patna edition, dated $16^{\text {th }}$ November, 2009.

${ }^{32}$ Gnanakan, Kingdom Concerns, 42.

${ }^{33}$ Stephen Neill, quoted by Ken Gnanakan, Kingdom Concerns, 42.

${ }^{34}$ Report of Commission I-VIII, 162.
} 
salvation"35 Regarding Indian religions, Shantanu Dutta rightly points out that "The key symptoms of our nation's downfall are corruption, intolerance, fanaticism, injustice and hypocrisy- all justified in the name of religion." 36 Dutta further writes, "It's not religion itself that disgusts but the manifestations of religion without any morality and a sense of integrity. That's what ails Indian religious life today.",37

2. Jesus Christ vs. other gods, goddesses and god-men: Jesus Christ is incomparable with any gods and goddesses or god-men. The task of Christian theology should be to identify with other cultures, as has been done since the beginning of the Church. But as we saw earlier, some of the Indian theologians have tried to fuse the best elements of Christianity and Hinduism. The result has been a set of beliefs that are neither Christian, nor Hindu, nor even the best of both. ${ }^{38}$ One feature of this form of syncretism defines Christ as a kind of avatar, a pale reflection of Krishna. The question is how far we can go in comparing Christ with other gods such as Krishna and Buddha or great men like Gandhi and Ambedkar. Neill gave the following counsel to Christian theologians trying to contextualize the gospel to Indian culture:

We must recognize afresh the immense spirituality of Jesus Christ. Under the influence of "comparative religion" and similar tendencies we have been too much inclined to find parallels to the works of Jesus here, there and everywhere, and to suppose that he can be filled into the category of prophet, or genius, or religious leader, or whatever we prefer. But this is simply wrong. Jesus cannot be understood in any dimensions other than His own. He has called into being a new world of reality in which only those are at home who call him Lord. When Christians use the word "God", they mean the Father of our Lord Jesus Christ and nothing else. This is a truth we forget at our peril. ${ }^{39}$

Jesus Christ is unique in his incarnation, in his holy life, suffering and death on the cross and the resurrection. For example, "in Hinduism a suffering deity is altogether unknown. Christ on the Cross is constantly misunderstood by the people of the East. In the myriad incarnations of India not one fails to be triumphant, and not one of them is found to suffer seriously for man"

3. The Gospel of Christ vs. other religions: There is an inherent difference between the Gospel of Christ and the non-Christian religions. "One of the great differences", writes Seamands, "between the non-Christian religions and the gospel is that there is no intrinsic relationship between these religions and their founders, while in

\footnotetext{
${ }^{35}$ Report of Commission I-VIII, 163.

${ }^{36}$ Shantanu Dutta, India Waiting for Dawn, (Mumbai: GLS Publishing, 2005), 133.

${ }^{37}$ Dutta, India Waiting, 133.

${ }^{38}$ S. D. Ponraj, An Introduction to Missionary Anthropology, (Chennai: Mission Educational Books, 1993), 87.

${ }^{39}$ Neill, quoted by Ponraj, An Introduction, 88,89.

${ }^{40}$ Report of Commission I-VIII, $167,168$.
} 
the Christian faith there is such relationship." ${ }^{41}$ Thus Christian religion is centered around a "person" and a "personal God-relationship" where as other religions are centered around several gods and goddesses and rules and rituals. Our gospel is always "the gospel of Jesus Christ" and not the "gospel of the Christian religion."

Our faith in the Gospel of Christ also gives us the answer why we proclaim our faith and why we try to bring people to Christ. A true disciple of Christ will not keep quiet but proclaim his faith because he has experienced it as the blind man who, when he was healed and then questioned by the Jewish leaders, said, "once I was blind and now I see." One of the greatest strengths of our Christian faith is that we have not only a "story to tell" but also an "experience to share" with our non-Christian neighbors. But this is not true with non-Christian religions.

\section{HAVING THE RIGHT ATTITUDE TOWARD OTHER FAITHS}

Seamands suggests a three-fold attitude towards people of other faiths: ${ }^{42}$

1) Assurance mingled with humility

2) Tolerance without compromise

3) Love mingled with respect

This attitude was rightly expressed when Dr. D. T. Niles of Sri Lanka used to say, "Evangelism is one beggar telling another beggar where to find bread." Dr. Hendrik Kraemer declared that our attitude towards non-Christians must be "a remarkable combination of downright intrepidity (boldness) and of radical humility."43 Seamands further comments, "The Christian witness must be tolerant in his attitude toward the views of other people, but at the same time be uncompromising in the claims of the gospel. To be tolerant means to be open-minded, fair-minded, sympathetic, understanding of the other person's position.... It has no right to surrender the truth. Toleration must be based on truth."

\section{CHRISTIAN RESPONSE TO OTHER FAITHS}

First, we should have a good understanding of non-Christian religions: One of the unique features of Edinburgh 1910 was the study on Hinduism and the Report was considered as "the most brilliant of the entire series, a masterpiece" which, according to Gairdner, reaches its highest point in its treatment of Hinduism. ${ }^{44}$ In today's context there are few writings on any of the non-Christian religions of India written by Indian Christians with missiological perspective. We are rightly challenged that, "Our aversion, and possibly fear, of the study of other religions certainly has crippled our witness to

\footnotetext{
${ }^{41}$ Seamands, Tell It, 68.

${ }^{42}$ Seamands, Tell It, 54-56.

${ }^{43}$ Quoted by John T. Seamands, Tell It, 55.

${ }^{44}$ Hedlund, The Roots, 35.
} 
those of other faiths, especially when perhaps more than $90 \%$ of Asia's population adhere to one non-Christian religion or another." 45

One of the reasons for the effectiveness of the early missionary work in India was that the pioneering missionaries gave themselves to the study of the Indian religions. For example, Bartholomaeus Ziegenbalg, the first Protestant missionary to India, made a study of the beliefs and practices of the Hindus. He made an in-depth study of Hinduism which resulted in the writing of a book entitled, The Genealogy of the Malabar Gods (1867). ${ }^{46}$ Another example was Henry Martin, the pioneer among the Muslims in North India, as we read that "hour after hour as the work proceeded Henry sat in close daily discussion with Muslim scholars, and he learned to know, as few men know, the Muslim outlook upon God and of daily life."

Today we need more missionary scholars to take up the study of Indian religions and to express in teachings and writings the beliefs of those religions, so that thousands of field missionaries and lay leaders in the local churches would be able to understand the religion of their own people and communicate the gospel effectively.

Second, we should understand the biblical theology of mission in relation to other religions: As we saw earlier, one of the reasons for the failure of fulfilling the dreams of the Edinburgh 1910, was the faulty theology of mission in relation to other religions, as expounded by William Hocking and later advocated at the Jerusalem Conference. Those challenges are still alive today. The dangers of syncretism and universalism are real for all those who want to share the gospel to the people of other faiths in their cultural mould. How do we guard against such syncretism? "To guard ourselves against the danger of syncretism, we have to take the uniqueness of Jesus seriously" says the veteran missionary Bruce Nicholls. Another feature that anchors us to biblical Christianity, according to Nicholls, is "a burning heart motivated to communicate the gospel to the lost.... Theology that is mission-centered is itself the best protection against syncretism., ${ }^{, 4}$

It is pointed out that, "Evangelical theology has sometimes been less than biblical in its total understanding of how we should perceive non-Christian religions and cultures"49 and that calls for our commitment to study the Bible and work out a practical biblical theology of mission in relation to other religions.

Third, we should understand the people groups' concept and God's time for each of them: Edinburgh 1910 stood for its excellent preparation in terms of field research and

\footnotetext{
${ }^{45}$ Hwa Yung, "The Resurgence of Asian Religions and Cultures", in Taking the Whole Gospel to Asia Today, (Chennai: Mission Educational Books, 1997). 72.

${ }^{46}$ S. D. Ponraj, The Pioneers of the Gospel, (Chennai: Mission Educational Books, 1996), 25.

${ }^{47}$ Ponraj, The Pioneers, 71.

${ }^{48}$ Ponraj, The Pioneers, 88.

${ }^{49}$ Hwa Yung, The Resurgence of Asian Religions and Cultures" in Taking the Whole Gospel to Asia Today (Chennai: Mission Educational Books, 1997), 73.
} 
gathering of data. The Report on Commission V "The Preparation of Missionaries" emphasized the study of "sociology" among other subjects. Commission IV made a study of non-Christian religions. It is important to note that following Edinburgh 1910, there was a great ingathering of people into the Church from the Dalits and Tribals in different parts of India. Both missionaries and national church leaders understood God's time for these poor and the oppressed people and without much hesitation they went ahead and led the "mass movements" to Christ. Bishop Azariah himself baptized on average 3000 people a year. ${ }^{50}$

Bishop J. W. Pickett of the Methodist Church wrote two outstanding books on these movements and "showed, first, that an overwhelming percentage of India's Christians owe their origins to group movements in the villages and, secondly, that for India group movements are to be expected, and to be accepted as the natural way of the movement."51

Today mission leaders and mission strategists should study and understand where the Lord is leading us in terms reaching the unreached people groups of other faiths. From this author's research, one of the immediate concerns for the Church in India should be how to bring the millions of "middle-caste" Hindus (Backward and Other Backward Classes), who are responsive to the gospel, into the fold of the church. They represent 52.5 per cent at the national level and it is a much higher per cent in some states, for example 63.5 per cent in Bihar. Most of the "middle-caste" follow popular Hinduism and are very open to the gospel in recent years.

\section{CONCLUSION}

The urgency of the unfinished task: It cannot be over emphasized that the urgency that was felt at Edinburgh 1910 is increased several fold today. Population growth, religious militancy, and the resurgence of non-Christian religions have made our task more difficult today than 100 years back. The 500 million-plus Buddhists of South East Asia, the nearly one billion Hindus in South Asia, the one billion plus Muslims of Central Asia and North Africa and the Middle East - these three blocks of religious people should be the focus to complete world evangelization. The Spirit of God is already moving among these three blocks of people and thousands are coming to Christ. We have to follow where the Spirit of God is working and accelerate the efforts with a sense of urgency to complete the task.

\section{BIBLIOGRAPHY}

Dutta, Shantanu. India Waiting for Dawn, A New Vision and A New Hope. Mumbai: GLS Publishing, 2005.

\footnotetext{
${ }^{50}$ Neill, A History, 479.

${ }^{51}$ Neill, A History, 480.
} 
Glaser, Ida. The Bible and Other Faiths. Leicester: Inter-Varsity Press, 2005.

Gnanakan, Ken. Kingdom Concerns. Leicester: Inter-Varsity Press, 1993.

Hedlund, Roger E. Roots of the Great Debate in Mission. Chennai: Evangelical Literature Service, 1981.

Neill, Stephen. A History of Christian Missions. Middlesex: Penguin Books, 1984.

Ponraj, S. Devasahayam. An Introduction to Missionary Anthropology. Chennai: Mission Educational Books, 2003.

. Pioneers of the Gospel. Chennai: Mission Educational Books, 1996.

Raj, Ebe Sunder. Conversion - A National Debate. Mussoorie: Nivedit Good Book Distributors Pvt. Ltd., 2004.

Report of Commission I-VIII- World Missionary Conference, Edinburgh, 1910. http:www.archive.org/bookreader/ 12-5-2009.

Seamands, John T. Tell it Well: Communicating the Gospel Across Cultures. Chennai: Mission Educational Books, 2003.

Yung, Hwa. "The Resurgence of Asian Religions and Culture: A Christian Response" In Taking the Whole Gospel to Asia Today. Chennai: Mission Educational Books, 1997. 